\title{
PENGARUH LINGKUNGAN KEWIRAUSAHAAN TERHADAP PENGEMBANGAN WIRAUSAHA DI KABUPATEN SLEMAN
}

\author{
Sri Haryani \\ bundaninik@gmail.com \\ Sekolah Tinggi Ilmu Manajemen YKPN Yogyakarta
}

\begin{abstract}
The emerge and growth of entrepreneurs are expected to reduce unemployment and increase the prosperity. The research objective is to analyze the effect of entrepreneurial environment (government policies and procedures, socio-economic conditions, skill of entrepreneurial and business, financial assistance, and non-financial assistance) to the growth of entrepreneurship. Entrepreneurial environment conducive expected to bring new entrepreneurs and develop existing entrepreneurs. Data were collected by a questionnaire distributed to 66 SMEs in Sleman. The sampling method using purposive sampling, while data analysis using SPSS 17.00. In this research, test instruments include the validity and reliability test, the results show that the entire statement item valid and reliable. Normality test, multicollinearity, and heteroscedasticity showed normal distribution of data, between independent variables does not occur multicollinearity problems, and found none problem heteroscedasticity. It can be concluded that the fators that affecting entrepreneurial growth in Sleman is socio-economic conditions, entrepreneurship and business skills, and financial assistance.
\end{abstract}

Key words: entrepreneur, entrepreneurial growth, entrepreneurial environment

\begin{abstract}
ABSTRAK
Pertumbuhan dan perkembangan wirausaha diharapkan dapat mengurangi jumlah pengangguran dan meningkatkan kemakmuran. Tujuan penelitian ini untuk menganalisis pengaruh lingkungan kewirausahaan (kebijakan dan prosedur pemerintah, kondisi sosial ekonomi, ketrampilan kewirausahaan dan bisnis, bantuan keuangan, dan bantuan non keuangan) terhadap pertumbuhan wirausaha. Lingkungan kewirausahaan yang kondusif diharapkan dapat melahirkan dan mengembangkan wirausaha. Data dikumpulkan dengan kuesioner yang disebarkan ke 66 pelaku UMKM di Kabupaten Sleman. Metode pengambilan sampel menggunakan purposive sampling, sedang analisis datanya menggunakan Program SPSS 17.00. Dalam penelitian ini dilakukan uji instrumen yang meliputi uji validitas dan uji reliabilitas yang hasilnya menunjukkan bahwa seluruh item pernyataan valid dan reliabel. Uji normalitas, multikolinearitas, dan heteroskedastisitas menunjukkan data berdistribusi normal, antar variabel independen tidak terjadi masalah multikolinearitas, dan tidak ditemukan masalah heteroskedastisitas. Dapat disimpulkan bahwa faktor-faktor yang mempengaruhi pengembangan wirausaha di Kabupaten Sleman adalah kondisi sosial ekonomi, ketrampilan kewirausahaan dan bisnis, dan bantuan keuangan.
\end{abstract}

Kata kunci : wirausaha, pertumbuhan wirausaha, lingkungan kewirausahaan

\section{PENDAHULUAN}

Kabupaten Sleman mempunyai potensi unggulan yang berupa komoditas pertanian, yang utama yaitu salak pondok dengan sentra di kecamatan Tempel, Turi, dan Pakem, mendong di kecamatan Minggir, kerajinan bambu di kecamatan Mlati, dan kambing PE di kecamatan Turi, Pakem dan Berbah. Pengembangan potensi unggulan di kabupaten Sleman dimaksudkan untuk meningkatkan perekonomian masyarakat dan mengurangi angka pengangguran. 
Upaya pengembangan potensi tersebut antara lain dilakukan dalam bentuk program pelatihan dan pendampingan bagi masyarakat. Hadisoegondo (2006) menyatakan bahwa untuk menjadikan seseorang menjadi wirausaha mandiri tidak cukup dilakukan dengan pelatihan dan pendampingan saja, harus diikuti dengan program untuk membangun suatu jaringan usaha, sehingga terbentuk sekelompok usaha sejenis (sentra) dan dalam bentuk pengembangannya menjadi jaringan kluster.

Untuk membentuk suatu sentra, pemerintah perlu menyediakan lingkungan kewirausahaan yang mendukung lahirnya wirausaha baru dan sekaligus dapat mengembangkan wirausaha yang ada. Secara umum lingkungan merupakan segala sesuatu yang ada disekitar obyek dan dapat mempengaruhi maupun dipengaruhi subyek tersebut. Dengan demikian lingkungan wirausaha merupakan segala sesuatu yang ada di sekitar wirausaha dan dapat mempengaruhi dan dipengaruhi oleh wirausaha. Dalam konteks upaya untuk melahirkan wirausaha baru dan mengembangkan wirausaha yang ada, yang dimaksud lingkungan adalah lingkungan eksternal yang terdiri dari pelanggan, pemasok, pesaing, kreditor, ekonomi, sosial, politik, teknologi, dan ekologi, namun tidak semua lingkungan eksternal ini mempunyai signifikansi yang sama dalam mempengaruhi lahir dan berkembangnya wirausaha.

Lahirnya usaha baru dimulai dari intensi atau minat seseorang untuk memulai usaha. Ketika seseorang mempunyai intensi untuk memulai usaha baru, perlu didukung dengan lingkungan yang dapat mendorong minat tersebut menjadi kenyataan. Dari berbagai lingkungan kewirausahaan di atas, tidak semua lingkungan memberikan duku- ngan pada tingkat yang sama dalam mewujudkan ide dan intensi berwirausaha menjadi kenyataan. Oleh karena itu perlu dilakukan analisis faktor-faktor lingkungan kewirausahaan yang mendukung terhadap pertumbuhan wirausaha, sehingga dapat disusun kondisi lingkungan kewirausahaan yang optimal untuk mendukung pertumbuhan wirausaha.

Penelitian dengan judul "Pengaruh Lingkungan Kewirausahaan Terhadap Pengembangan Wirausaha Di Kabupaten Sleman" dilakukan di Kabupaten Sleman" dengan tujuan untuk menganalisis lingkungan kewirausahaan seperti apa yang dapat mendukung pertumbuhan wirausaha. Dengan diketahuinya lingkungan kewirausahaan yang kondusif untuk pertumbuhan wirausaha diharapkan akan mempermudah pihak-pihak yang terkait dalam melahirkan wirausaha baru. Hasil penelitian ini diharapkan dapat memberikan masukan bagi pemerintah, lembaga keuangan, lembaga sosial, dan dunia pendidikan dalam melahirkan wirausaha baru.

\section{TINJAUAN TEORETIS \\ Pertumbuhan Wirausaha}

Pertama kali gagasan tentang kewirausahaan dan pertumbuhan ekonomi memiliki hubungan yang sangat erat dan positif disampaikan oleh Schumpeter pada tahun 1911, di mana peningkatan jumlah wirausaha menyebabkan peningkatan pertumbuhan ekonomi suatu negara (Bygrave, 2004). Ada lima alasan yang melatarbelakangi gagasan Schumpeter ini, yakni: (1) wirausaha mengenalkan produk baru dan kualitas baru dari suatu produk, (2) wirausaha mengenalkan metode baru berproduksi yang lebih komersial, baik berdasarkan pengalaman maupun hasil kajian ilmiah dari suatu penelitian (3) wirausaha membuka pasar baru, baik dalam negeri ataupun di negara yang sebelumnya belum 
ada pasar (4) wirausaha menggali sumber pasokan bahan baku baru bagi industri setengah jadi atau industri akhir, dan (5) wirausaha menjalankan organisasi baru dari industri apapun. Wirausaha mendorong peningkatan produktivitas yang selanjutnya akan mendorong pertumbuhan ekonomi negara.

Pentingnya kewirausahaan mendorong negara untuk merencanakan program kewirausahaan melalui amanat GBHN 1993 Angka 8 butir $\mathrm{f}$ "pembinaan usaha ekonomi rakyat diutamakan pada pengembangan kewirausahaan" yang selanjutnya diimplementasikan melalui INPRES No. 4 Tahun 1995 Tentang Gerakan Nasional memasyarakatkan dan membudayakan Kewirausahaan. Dalam perkembangan terakhir ini, justifikasi perhatian pemerintah antara lain didasarkan pada data Kementrian Koperasi dan UKM pada tahun 2013 jumlah keseluruhan unit usaha baik mikro, kecil, dan menengah maupun besar sebanyak 57.900.787, mampu menyerap 117.681.244 tenaga kerja, dan sumbangannya terhadap PDB sebesar 9.014.951,2.

Penelitian Haryani (2013) menunjukkan bahwa karakteristik personal (personality characteristics) yang terdiri dari kebutuhan untuk berprestasi (need for achievement) dan efikasi diri (self efficacy) secara signifikan berpengaruh terhadap intensi wirausaha. Kebutuhan untuk berprestasi ini tercermin dalam perilaku yang menunjukkan tanggung jawab terhadap keputusan yang diambil dan mengawal keputusan tersebut sampai pada pencapaian tujuan yang diinginkan. Pada umumnya wirausaha yang sukses mempunyai kebutuhan untuk berprestasi pada tingkat yang tinggi. Seseorang dengan efikasi diri tinggi mempunyai komitmen yang tinggi untuk menyelesaikan masalah dan tidak mudah menyerah ketika keputusan yang telah diambil tidak seperti yang diharapkan. Marini dan Hamidah (2014) yang melakukan penelitian pada siswa SMK Boga di Yogyakarta menyimpulkan adanya pengaruh efikasi diri lingkungan keluarga, dan lingkungan sekolah secara parsial maupun simultan terhadap minat berwirausaha.

Seseorang dengan intensi untuk berwirausaha akan memiliki kesiapan dan kemajuan yang lebih baik dalam usaha yang dijalankan dibandingkan seseorang tanpa intensi berwirausaha. Intensi kewirausahaan diyakini berkaitan dengan perilaku terbukti dapat menjadi cerminan dari perilaku yang sesungguhnya. Oleh karena itu pemahaman tentang intensi seseorang untuk berwirausaha (entrepreneurial intention) dapat mencerminkan kecenderungan orang untuk mendirikan usaha secara riil.

Bygrave (2004) menyebutkan bahwa faktor internal yang dapat memicu lahirnya wirausaha antara lain terdiri dari pencapaian, lokus kendali (locus of cotrol), toleransi, pengambilan risiko, nilai-nilai pribadi, pendidikan dan pengalaman. Lahirnya wirausaha juga dipicu oleh faktor faktor eksternal seperti peluang, adanya wirausaha yang sukses/sebagai panutan, sumberdaya, inkubator, kebijakan pemerintah, pesaing, pelanggan, pemasok, dan investor/bank.

Selain menambah jumlah wirausaha, dalam pertumbuhan wirausaha ini pemerintah juga bermaksud meningkatkan kelas wirausaha ke tingkat yang lebih tinggi. Berdasar data Kementrian Koperasi dan UKM, pada tahun 2013 terdapat 53.504.416 unit usaha mikro, 568.397 unit usaha kecil, 42.008 unit usaha menengah, dan 5.150 unit usaha besar. Pemerintah bermaksud meningkatkan tingkatan wirausaha, sehingga terjadi pergeseran proporsi dari unit usaha 
mikro, ke unit usaha kecil, menengah, dan besar.

Seperti halnya benih yang disemai ditanah yang subur, maka kemungkinan besar benih akan tumbuh dan berkembang. Demikian halnya dengan lingkungan bisnis yang kondusif, maka semakin besar kemungkinan bahwa bisnis baru akan lahir dan bisnis yang sudah ada akan berkembang. Orang akan lebih mungkin didorong dan merasa kompeten untuk memulai bisnis ketika lingkungan sosial menghargai kewirausahaan, ketika berbagai peluang tersedia bagi pengusaha, dan ketika mereka memiliki pengetahuan dan keterampilan yang dibutuhkan untuk memulai dan mengelola sebuah bisnis yang cukup. Kemauan dan kemampuan untuk memulai bisnis dapat lebih ditingkatkan jika pengusaha potensial (calon pengusaha) tidak menghadapi rintangan selama proses awal pendirian usahanya dan ketika mereka yakin bahwa tenaga ahli bisa diperoleh dengan mudah bila diperlukan. Pemerintah baik secara langsung maupun tidak langsung mempengaruhi perkembangan lingkungan yang dapat mendukung kewirausahaan.

Kebutuhan untuk pengembangan lingkungan yang kondusif berbeda-beda, di negara-negara berkembang kebutuhan akan kewirausahaan lebih besar dari pada di negara maju karena rendahnya tingkat aktivitas kewirausahaan. Selain itu kebutuhan untuk lingkungan yang kondusif akan lebih besar dalam kasus usaha kecil, karena usaha kecil memiliki sedikit kontrol atas lingkungan di mana mereka beroperasi. Perusahaan skala kecil mempunyai kekuatan menawar (bargaining power) yang lemah yang biasanya diperlukan untuk mempengaruhi lingkungan suatu perusahaan.

\section{Lingkungan Kewirausahaan}

Kewirausahaan beroperasi dalam suatu lingkungan yang dinamis, yang pada umumnya tidak dapat dikendalikan oleh wirausaha itu sendiri. Lingkungan kewirausahaan itu sendiri sangat luas, sehingga penelitian yang dilakukan peneliti-peneliti terdahulu juga bervariasi secara luas. Literatur-literatur lingkungan kewirausahaan secara umum membahas lingkungan kewirausahaan yang meliputi kerangka hukum dan kelembagaan, kehadiran pengusaha berpengalaman, kehadiran tenaga kerja terampil, aksesibilitas pemasok, aksesibilitas pelanggan atau pasar baru, tingkat kompetisi antar perusahaan, kebijakan pemerintah yang mendukung, penyediaan pelatihan dan dukungan layanan, dan infrastruktur. Selain itu, karakteristik orang, keterampilan, pengalaman, dan motivasi, memainkan peran penting dalam penciptaan usaha baru. Gnyawali dan Fogel (1994) mengelompokkan lingkungan kewirausahaan menjadi lima (5) kelompok yaitu kebijakan dan prosedur pemerintah, kondisi sosial dan ekonomi, keterampilan kewirausahaan dan bisnis, bantuan keuangan, dan bantuan non keuangan.

Penelitian yang dilakukan Supriyanto (2009) menunjukkan adanya faktor di luar ekonomi, misalnya kultur di Indonesia yang masih menganggap profesi wirausaha sebagai profesi kurang terhormat, sehingga banyak orang tua yang lebih menginginkan anak-anaknya berprofesi sebagai PNS, ABRI atau Pegawai Swasta. Oleh karena itu dalam beberapa kasus ditemukan adanya orang tua yang kurang mendukung proses dan perkembangan wirausaha.

Penelitian yang dilakukan Ayuningtias dan Ekawati (2015) terhadap mahasiswa Fakultas Ekonomi Universitas Tarumanagara menunjukkan bahwa lingkungan keluarga, lingkangan kampus, kepribadian, dan motivasi baik secara parsial maupun simultan berpengaruh terhadap minat 
berwirausaha. Penelitian Marini dan Hamidah (2014) menyimpulkan adanya pengaruh efikasi diri lingkungan keluarga, dan lingkungan sekolah secara parsial maupun simultan terhadap minat berwirausaha. Lingkungan keluarga dapat menjadi lingkungan yang kondusif untuk menumbuhkan minat berwirausaha dalam bentuk dorongan kemandirian, prestasi, dan tanggung jawab. Selain itu orang tua juga dapat memberikan dukungan moril dalam bentuk kepercayaan dan pemberian ide/pemikiran serta dukungan materiil dengan memberikan modal, penyediaan alat/perlengkapan usaha atau lokasi/tempat usaha. Sesuai dengan misi Sekolah Menengah Kejuruan untuk mencetak lulusan yang siap berwirausaha, maka sekolah perlu mentransformasikan karakteristik wirausaha kepada siswanya. Tansformasi tersebut dapat dilakukan melalui lingkungan sosial sekolah yang terdiri dari guru, tenaga kependidikan, teman-teman sekolah, dan budaya sekolah serta lingkungan non sosial sekolah yang terdiri dari kurikulum, program, dan sarana prasarana.

Penelitian Wulandari (2009) menunjukkan lingkungan eksternal dan internal baik secara memiliki pengaruh positif terhadap orientasi wirausaha. Lingkungan eksternal diukur melalui perubahan lingkungan, sumber daya, peraturan, persaingan, internasionalisasi, teknologi, dan karakteristik industri sedang lingkungan internal diukur melalui ukuran perusahaan, struktur organisasi, strategi perusahaan, proses pembuatan strategi, sumber daya perusahaan, budaya perusahaan, dan karakteristik tim manajemen puncak. Sementara penelitian yang dilakukan Ferediouni (2010) menunjukkan bahwa lingkungan eksternal mempengaruhi motivasi masyarakat Iran untuk memulai bisnis. Agar masyarakat termotivasi untuk memulai bisnis diperlukan kebijakan pemerintah dalam hal adanya perundangan dan peraturan yang berpihak pada bisnis, penurunan pajak untuk usaha kecil, memberikan peluang usaha bagi usaha kecil, pemberian pinjaman, dan mempermudah perizininan untuk usaha baru.

Kajian teori dan beberapa penelitian terdahulu menunjukkan pentingnya lingkungan kewirausahaan dalam menumbuhkan kewirausahaan di masyarakat. Meskipun teori dan penelitian-penelitian tentang lingkungan kewirausahaan di atas dengan berbagai variasi namun intinya menyatakan bahwa lingkungan kewirausahaan baik lingkungan internal maupun eksternal berpengaruh terhadap pertumbuhan wirausaha. Pengaruh tersebut dapat bersifat langsung maupun tidak langsung. Dalam penelitian ini yang termasuk dalam lingkungan kewirausahaan adalah kebijakan dan prosedur pemerintah, kondisi sosial ekonomi, kewirausahaan dan ketrampilan, bantuan keuangan, dan bantuan non keuangan.

\section{Kebijakan dan Prosedur Pemerintah}

Dalam suatu sistem ekonomi yang kompleks, diperlukan peran pemerintah sebagai regulator yang akan mengatur sistem yang ada sehingga sistem dapat berjalan dan sesaui dengan realitas sosial. Fungsi regulatori tersebut antara lain diwujudkan dalam bentuk peraturan perundangan yang dimaksudkan untuk mengatur sistem perekonomian. Beberapa peraturan perundangan yang diharapkan dapat mendorong pertumbuhan wirausaha antara lain hukum kepailitan, dengan tujuan untuk melindungi kepentingan debitur maupun krediturnya. Undang-undang yang me- 
lindungi hak-hak kepemilikan (property right), yang mencakup hak individu dalam bentuk Hak Cipta (UU No 9 tahun 2001) maupun hak industri dalam bentuk Paten (UU no 14 tahun 2001) dan Merek (UU no 15 tahun 2001). UU No 5 tahun 1999 tentang Larangan Praktek Monopoli dan Persaingan Usaha Tidak Sehat dengan tujuan untuk menjaga kepentingan umum dan meningkatkan efisiensi ekonomi nasional sebagai salah satu upaya untuk meningkatkan kesejahteraan rakyat dan mewujudkan iklim usaha yang kondusif melalui pengaturan persaingan usaha yang sehat sehingga menjamin adanya kepastian kesempatan berusaha yang sama bagi pelaku usaha besar, pelaku usaha menengah, dan pelaku usaha kecil.

Pemerintah melakukan pembatasan impor yang dikenal dengan pembatasan kuota misalnya untuk produk buah-buahan dan pakaian jadi guna melindungi perusahaan di dalam negeri. Pembatasan ekspor juga dilakukan, dengan tujuan untuk memenuhi kebutuhan di dalam negeri dan untuk meningkatkan nilai tambah bagi produk yang akan diekspor. Selain itu pembatasan impor juga dilakukan dengan mengenakan tarif bea masuk yang relatif tinggi, sehingga harga produk impor tersebut sampai di tangan konsumen dengan harga yang relatif mahal.

Kebijakan pemerintah yang berpihak pada wirausaha antara lain diwujudkan dalam bentuk keringanan pajak, pemberian kredit dengan bunga murah, pendidikan, pelatihan, dan inkubator, serta bantuan pemasaran dan teknologi. Dengan adanya kebijakan pemerintah ini harga barang dalam negeri diharapkan menjadi murah, sehingga mampu bersaing dengan produkproduk impor. Apabila produk tersebut akan di ekspor, dapat memenuhi ketentuan standar yang berlaku dan mampu bersaing dengan produk negara lain.

Kemudahan persyaratan prosedural untuk pengurusan berbagai perizinan usaha yang meliputi Surat Izin Tempat Usaha (SITU), Surat Izin Usaha Perdagangan (SIUP), dan Tanda Daftar perusahaan (TDP) dilakukan oleh pemerintah tingkat kabupaten/kota dengan menyusun pelayanan satu atap. Pelaku usaha yang melakukan pengurusan izin tidak perlu mendatangi berbagai kantor dan berbagai meja, sehingga menghemat waktu, tenaga, dan biaya. Bagi perusahaan manfaktur yang izin usahanya harus dilampiri dengan AMDAL, prosedur pengurusannya juga dipermudah.

Pusat Layanan Usaha Terpadu (PLUT) yang berada di bawah Kementerian Koperasi dimaksudkan sebagai lembaga pendamping bagi pelaku usaha. Para pelaku usaha dapat mengadukan masalahnya ke PLUT, yang akan ditangani oleh konsultan bisnis yang ada di PLUT tersebut. Terhadap permasalahan pemasaran produk-produk UMKM yang sering dikeluhkan oleh pelaku usaha, saat ini kementerian bekerja sama dengan Kadin menyusun e-commerce yaitu ukmmarket.co.id yang merupakan pusat jual beli online untuk produk UKM Indonesia.

Semua upaya pemerintah di atas dimaksudkan untuk dapat meningkatkan pertumbuhan dan perkembangan wirausaha. Penelitian yang dilakukan Setyawati et al. (2013) menyatakan bahwa pemerintah berperan dalam pertumbuhan usaha mebel dan anyaman rotan di Kabupaten Hulu Sungai Utara, Kalimantan Selatan. Dari kajian teori dan penelitian terdahulu dapat disusun hipotesis pertama $\left(\mathrm{H}_{1}\right)$ : kebijakan dan prosedur pemerintah (KPP) berpengaruh terhadap pertumbuhan wirausaha $(\mathrm{PW})$. 


\section{Kondisi Sosial dan Ekonomi}

Kondisi lingkungan menunjukkan adanya hubungan antar individu di suatu wilayah atau daerah tertentu atau seringkali merujuk pada kondisi masyarakat tertentu. Sikap yang positif dari masyarakat terhadap kewirausahaan dan dukungan masyarakat luas untuk kegiatan kewirausahaan akan memotivasi orang untuk memulai usaha baru. Sebaliknya, sikap yang negatif terhadap kewirausahaan dapat menyebabkan kewirausahaan tidak berhasil. Faktor-faktor psikologis yang terlanjur terbentuk di masyarakat yang bersifat negatif terhadap wirausaha antara lain pelit, egois, tidak jujur, agresif dan materialistik, sedangkan yang bersifat positif antara lain pandangan bahwa wirausaha adalah inovator, kreatif, rajin, ulet, mempunyai motivasi tinggi, dan mempunyai naluri untuk melihat peluang.

Peningkatan efektivitas program pengembangan kewirausahaan memerlukan dukungan yang luas dari seluruh struktur masyarakat dan organisasi yang ada. Penelitian Haryani (2013) menunjukkan bahwa lingkungan berpengaruh positif terhadap intensi berwirausaha, di mana orang tua dan kerabat dapat membantu calon pengusaha dalam membangun jaringan, bantuan keuangan yang dibutuhkan, serta dukungan moral. Demikian dengan penelitian Crissanti dan Tjiptono (2012) menunjukkan bahwa instrumental readiness seperti akses ke sumber modal, akses informasi, dan jaringan sosial berpengaruh positif terhadap intensi berwirausaha.

Perkembangan saat ini menunjukkan peningkatan jumlah orang yang memilih untuk memulai usaha sendiri. Data Kementerian Koperasi dan UKM menunjukkan bahwa pada tahun 2013 terdapat 57.895.721 unit usaha mikro kecil dan menengah
(UMKM), dengan rata-rata pertumbuhan per tahun $4,23 \%$. Bidang usaha UMKM bermacam-macam, meskipun demikian mayoritas UMKM bergerak di bidang perdagangan, industri rumah tangga, dan berbagai jasa seperti cuci mobil, loundry, bengkel, tukang jahit, salon, rumah makan, dan transportasi.

Kesuksesan finansial yang dapat diperoleh dari mereka yang membangun usaha sendiri jauh lebih banyak dibanding yang bekerja sebagai karyawan, PNS, maupun militer mendorong orang untuk memilih memulai usaha sendiri. Dari mereka yang sukses menjadi wirausaha tersebut, kemudian masyarakat menganalisis karakteristik wirausaha yang tidak dimiliki oleh bukan wirausaha antara lain berani mengambil risiko, kerja keras dan disiplin, mandiri dan realistik, berpikir positif dan bertanggung jawab, dapat mengendalikan emosi, dan berusaha mencari jalan keluar dari setiap permasalahan. Dari karakteristik-karakteristik ini, kemudian seseorang yang mempunyai intensi untuk berwirausaha akan meniru karakeristik tersebut.

Bagi wirausaha yang sukses, pemerintah menganugerahkan penghargaan Upakarti karena dedikasinya dalam mengembangkan industri kecil dan menengah. Penghargaan ini merupakan salah satu bentuk pemenuhan kebutuhan untuk berprestasi bagi wirausaha. Secara teoritis kebutuhan untuk berprestasi ini diyakini menjadi faktor pendorong intensi berwirausaha, seperti hasil penelitian Winarno (2010) yang menyebutkan adanya hubungan positif antara motivasi berprestasi dengan sikap wirausaha. Namun dalam penelitian Crissanti dan Tjiptono (2012) kebutuhan untuk berprestasi tidak berpengaruh ter- 
hadap intensi berwirausaha mahasiswa di DIY. Hasil penelitian Janah dan Winarno (2015) juga menunjukkan bahwa motivasi berprestasi tidak berpengaruh secara signifikan terhadap intensi berwirausaha siswa SMK N I Banyuwangi.

Pertumbuhan ekonomi akan mempengaruhi lahir dan berkembangnya wirausaha, karena dengan ekonomi yang berkembang maka kesempatan usaha juga ikut berkembang. Peningkatan Produk Domestik Bruto (PDB) sebagai salah satu indikator pertumbuhan ekonomi akan menyebabkan peningkatan daya beli, sehingga akan menyerap produk yang ada di pasar. Kebijakan mempermudah masuknya investasi asing ke Indonesia maupun investasi pemerintah akan menyebabkan peningkatan barang dan jasa yang dihasilkan yang selanjutnya akan menyebabkan pertumbuhan ekonomi.

Berdasar penelitian terdahulu dan landasan teori di atas disusun hipotesis kedua $\left(\mathrm{H}_{2}\right)$ : kondisi sosial ekonomi (KSE) berpengaruh terhadap pertumbuhan wirausaha (PW).

\section{Ketrampilan Kewirausahaan dan Bisnis}

Ketrampilan kewirausahaan dapat diberikan secara formal melalui pendidikan dan pelatihan yang diberikan oleh lembaga pendidikan maupun lembaga pelatihan. Hasil penelitian Rosmiati et al. (2015) menunjukkan bahwa sikap dan motivasi tidak berpengaruh terhadap minat mahasiswa untuk berwirausaha. Hal ini disebabkan ketidakpahaman mahasiswa untuk menjalankan usaha, kurang menyukai tantangan, dan kurang berani mengambil risiko. Memberikan wawasan, pelatihan, dan bimbingan wirausaha merupakan salah satu pilihan untuk memupuk jiwa kewirausahaan dengan harapan dapat mengubah pendapat mahasiswa bahwa wira- usaha menjanjikan kehidupan yang lebih baik.

Melalui INPRES Nomor 4 Tahun 1995 tentang Gerakan Nasional Memasyarakatkan dan Membudayakan Kewirausahaan, pemerintah menetapkan bahwa konsep kewirausahaan harus menjadi materi resmi dalam pendidikan di sekolah-sekolah menengah dan atas dan disebarluaskan bagi semua pihak, khususnya generasi muda. Manurung (2013) menyebutkan perlunya kewirausahaan sekolah untuk menciptakan sesuatu yang baru, unik bermakna (bernilai), melalui pemikiran kreatif dan inovatif demi terciptanya peluang, ruang, dan uang. Dalam perkembangannya di beberapa Perguruan Tinggi di Indonesia seperti di STIM YKPN Yogyakarta sudah di bentuk Pusat Wirausaha, dan bahkan Universitas Ciputra mengkalim universitasnya sebagai "Entrepreneur University". Selain itu beberapa institusi juga berperan dalam pengembangan kewirausahaan, salah satunya Program Wirausaha Mandiri dari Bank Mandiri.

Program peningkatan ketrampilan kewirausahaan dan bisnis disesuaikan dengan masalah yang dihadapi wirausaha, sehingga dapat membantu menyelesaikan masalah yang dihadapi dan meningkatkan motivasi bagi calon wirausaha untuk memulai usaha baru. Hasil penelitian Dian et al. (2014) menunjukkan bahwa pelatihan kewirausahaan mampu meningkatkan kualitas jiwa wirausaha yang dibuktikan dengan munculnya aspek kreativitas, inovasi, dan keberanian dalam mengambil risiko. Pelatihan pembukuan berjalan baik, terbukti dengan munculnya kemampuan UMKM dalam menentukan biaya produksi, catatan persediaan bahan baku dengan metode FIFO, dan pembuatan laporan keuangan dengan aplikasi MYOB.

Selain menjadi modal utama pembangunan, wirausaha yang kuat dan handal menjadi bearing dalam menghadapi gejolak 
ekonomi global, serta menghadapi era baru liberalisasi ASEAN Economic Community (Sijabat, 2012). Untuk itu wirausaha khususnya UMKM memerlukan peningkatan kapasitas yang mencakup akses informasi, teknologi, pembiayaan, dan pasar.

Secara umum wirausaha pada skala kecil dan menengah menghadapi kendala dalam mengakses informasi, yang antara lain ditunjukkan dengan penggunaan jaringan telepon, jaringan telepon bergerak, dan penggunaan website yang masih relatif rendah. Selain itu, bagi wirausaha yang sudah menggunakan jaringan telepon dan telepon bergerakpun proporsi penggunaanya untuk mencari peluang usaha relatif lebih kecil dibanding untuk keperluan keluarga dan sosial. Pengembangan dalam bidang desain dan teknologi sebagaimana dimaksud pada pasal 16 UU Nomor 20 tahun 2008 dilakukan dengan cara (1) meningkatkan kemampuan di bidang desain, teknologi, dan pengendalian mutu; (2) meningkatkan kerja sama dan alih teknologi; (3) meningkatkan kemampuan UKM di bidang penelitian untuk pengembangan desain dan teknologi baru; 4) memberikan insentif kepada UMKM yang mengembangkan teknologi dan melestarikan lingkungan hidup; serta (5) mendorong sertifikasi UMKM unutk memperoleh sertifikat hak atas kekayaan intelektual.

Hasil kajian Kementerian Koperasi dan UKM tahun 1999 menunjukkan adanya ketertinggalan UMKM di bidang teknologi yang disebabkan oleh (1) ketidakmampuan membeli teknologi karena profit margin UMKM yang relatif rendah; (2) lemahnya self learning dalam mengadaptasi teknologi baru; dan (3) akses informasi pasar input maupun output serta informasi teknologi yang masih kurang. Pusat Layanan Usaha Terpadu
(PLUT) yang merupakan lembaga yang menyediakan jasa non finansial yang menyeluruh dan terintegrasi bagi koperasi dan UKM juga menyediakan konsultan teknis untuk membantu UMKM. Sementara itu dalam beberapa kasus, bantuan teknologi yang berupa peralatan yang diberikan pemerintah tidak sesuai dengan kebutuhan UMKM, yang disebabkan pada proses pengadaannya tidak mengikutsertakan UMKM sebagai pihak yang akan menggunakan. Hipotesis ketiga yang disusun adalah: $\mathrm{H}_{3}$ : ketrampilan kewirausahan dan bisnis (KKB) berpengaruh terhadap pertumbuhan wirausaha (PW).

\section{Bantuan Keuangan}

Kebijakan pemerintah melalui Bank Indonesia dalam pengembangan UMKM untuk menjembatani kesenjangan antara UMKM dan perbankan dalam rangka meningkatkan akses keuangan dilakukan dengan memperbaiki 3 kesenjangan yaitu kesenjangan skala, formalitas, dan informasi (Wibowo dan Artati, 2012). Kesenjangan skala muncul karena adanya perbedaan antara jumlah kebutuhan dana UMKM yang umumnya relatif kecil sementara jumlah kredit yang diberikan perbankan relatif besar. Kesenjangan formalitas disebabkan ketidakmampuan UMKM dalam memenuhi persyarakat administrasi bank, khususnya dalam hal agunan, sedangkan kesenjangan informasi muncul karena ketidaktahuan UMKM terhadap prosedur dan produk perbankan, serta ketidaktahuan perbankan mengenai UMKM yang dapat dibiayai.

Perusahaan modal ventura yang diawali dengan pembentukan PT Bahana Pembinaan Usaha Indonesia (BPUI) dengan tujuan utama untuk berinvestasi pada perusahaan yang memiliki resiko tinggi sehingga tidak memenuhi persyaratan standar sebagai perusahaan terbuka ataupun tidak memenuhi standar untuk memperoleh modal pinjaman 
dari perbankan (tidak bankable). Pada umumnya modal ventura disertakan pada perusahaan yang baru berdiri, sehingga belum memiliki riwayat operasional yang dapat dijadikan pertimbangan dalam analisis pemberian kredit bank. Meskipun demikian, operasionalisasi BPUI dalam membantu wirausaha mengakses dana belum optimal, karen PT BPUI yang dimiliki pemerintah ini meskipun tidak murni berorientasi laba namun "tidak boleh membebani anggaran negara".

Kredit Untuk Rakyat (KUR) merupakan kredit modal kerja dan/atau kredit investasi yang dibiayai sepenuhnya oleh dana perbankan, diberikan kepada koperasi dan wirausaha dalam skala mikro, kecil, dan menengah yang produktif, serta secara bisnis layak tetapi dari sudut pandang perbankan belum layak atau belum bankable. Besaran nilai pinjaman dari KUR mikro maksimum Rp 25 juta dan KUR ritel maksimum Rp 500 juta, dengan suku bunga awal 9\% kemudian diturunkan menjadi 7\%. Penurunan suku bunga pinjaman ini dapat mengurangi beban yang ditanggung wirausaha, namun dengan menggunakan bank sebagai lembaga penyalurnya maka jumlah yang dapat mengakses kredir KUR belum optimal. Karena menurut UU Nomor 36 tahun 2013 dalam menyalurkan pinjaman, bank harus menerapkan prinsip kehati-hatian dengan menerapkan prinsip 5C sehingga wirausaha akan terkendala dengan persyaratan collateral/agunan.

Berbagai bantuan keuangan di atas dimaksudkan untuk dapat menumbuhkan wirausaha di Kabupaten Sleman. Hipotesis keempat $\left(\mathrm{H}_{4}\right)$ yaitu bantuan keuangan (BK) berpengaruh terhadap pertumbuhan wirausaha. (PW)

\section{Bantuan Non Keuangan}

Tingkat ketrampilan kewirausahaan dan bisnis para wirausaha berbeda-beda, sehingga tidak semua mampu mengatasi masalah yang mereka hadapi pada berbagai tahap perkembangan bisnis mereka. Berbagai jenis pelatihan dan pendampingan dari pemerintah dan lembaga lain diharapkan dapat mengatasi masalah mereka. Dian et al. (2014) menemukan bahwa pelaku UMKM kripik Salak di kabupaten Sleman dalam proses produksinya belum menggunakan continuous sealler, kemasan tidak tertutup dengan sempurna sehingga kripik Salak cepat "mlempem". UMKM tersebut kemudian mendapat hibah 1 unit mesin continuous sealler dan pendampingan pengoperasian dan perawatan mesin. Untuk meningkatkan produktivitas, UMKM ini juga mendapat hibah 1 unit genset, yang digunakan untuk menggerakkan mesin vacuum frying, apabila terjadi pemadalan listrik. Sedang untuk masalah pemasaran produk, UMKM ini difasilitasi untuk pembuatan desain web untuk meningkatkan pemasarannya sehingga dapat melalui $e$ commerce. Perkembangan teknologi informasi dan transportasi diharapkan dapat mendekatkan wirausaha ke pasar lokal, nasional, maupun pasar luar negeri.

Untuk menanggulangi masalah persyaratan agunan seperti diuraikan di atas, pemerintah menyusun beberapa program yang dimaksudkan dapat mengatasi masalah agunan antara lain dengan Lembaga Pengembangan Dana Bergulir (LPDB), Perum Jaminan Kredit Indonesia (Jamkrindo), PT Permodalan Nasional Madani (PT Madan), dan Perusahan Penjamin Kredit Daerah (PPKD) yang saat ini baru didirikan di Jawa Timur dan Bali. Wacana pem- 
bentukan lembaga penjamin modal yang sesuai dengan karakteristik wirausaha skala mikro dan kecil yaitu bahwa lembaga tersebut dibentuk di kalangan mereka sendiri sehingga sudah saling mengenal dan sudah ada saling kepercayaan dan didasarkan prinsip tolong menolong dan kesetiakawanan. Lembaga tersebut hendaknya berbadan hukum, dengan bentuk yang disepakati diantara mereka (Syarif, 2012).

Semua bisnis memerlukan dukungan jaringan, terlebih bagi bisnis yang baru saja berdiri yang mempunyai keterbatasan sumberdaya dan sumberdana. Arti penting pembentukan jaringan bisnis semakin meningkat dengan diberlakukanya perdagangan bebas dan MEA. Para pelaku usaha dalam skala apapun perlu bersinergi untuk menghadapi musuh bersama yaitu serbuan produk dan perusahaan asing ke Indonesia. Bentuk-bentuk kegiatan jaringan kewirausahaan antara lain dalam kegiatan promosi, pertukaran informasi, pembelian bahan baku, kegiatan riset dan pengembangan, serta pengunaan fasilitas pendukung untuk kegiatan bersama. Inkubator bisnis menyediakan fasilitas bagi percepatan penumbuhan wirausaha melalui fasilitas dan layanan, khususnya bagi bisnis yang baru saja berdiri.

Suatu perusahaan yang masih berada di tahap awal (early stage) dapat memanfaatkan fasilitas dan layanan yang disediakan oleh inkubator, sehingga dapat mengatasi masalah yang dihadapi dalam menjalankan bisnisnya. Bagai perusahaan yang sudah melewati tahap awal, adanya inkubator diharapkan dapat mengembangkan dan memperkuat usaha yang dijalankannya. Pengusaha mikro dan kecil merupakan bagian terbesar dari pelaku bisnis di Indonesia, sehingga mempunyai peran yang strategis dalam pengembangan ekonomi nasional.

Berbagai bantuan seperti adanya inkubator, kegiatan jaringan kewirausahaan antara lain dalam kegiatan promosi, pertukaran informasi, pembelian bahan baku, kegiatan riset dan pengembangan, serta pengunaan fasilitas pendukung untuk kegiatan bersama dimaksudkan untuk menumbuhkan wirausaha. Hipotesis terakhir $\left(\mathrm{H}_{5}\right)$ yaitu bantuan non keuangan (BNK) berpengaruh terhadap pertumbuhan wirausaha (PW).

\section{METODE PENELITIAN}

Penelitian ini dilakukan di Kabupaten Sleman, dengan populasi wirausaha di Kabupaten Sleman Daerah Istimewa Yogyakarta. Dalam penelitian akan dilakukan analisis multivariate (regresi linear berganda) maka jumlah anggota sampel minimal 10 kali dari jumlah variabel yang diteliti (Wiyono, 2011). Sampel penelitian ini menggunakan 6 variabel, maka jumlah minimal responden 60 . Metode pengambilan sampel menggunakan Nonprobability Sampling, yaitu dengan Purposive Sampling, yaitu sampel dipilih dari anggota populasi yang sudah menjalankan usahanya minimal 4 tahun sehingga sampel memahami adanya kebijakan dan prosedur pemerintah yang berhubungan dengan wirausaha, serta adanya bantaun keuangan dan non keuangan yang dapat membantu wirausaha pada saat memulai maupun dalam mengelola usahanya.

Pengumpulan data dengan kuesioner, sedang skala pengukuran dengan menggunakan skala likert dengan skor 1 sampai 5, di mana skor 1 menunjukkan sangat tidak setuju dan skor 5 menunjukkan sangat setuju dengan pertanyaan/pernyataan. Analisis data dengan menggunakan bantuan Program SPSS 17.00, yang meliputi uji instrumen, uji asumsi klasik, uji hipotesis, 
dan analisis regresi linear berganda yang dimaksudkan untuk mengetahui hubungan fungsional dan kausal antara kebijakan dan prosedur pemerintah, kondisi sosial ekonomi, ketrampilan kewirausahan dan bisnis, bantuan keuangan, bantuan non keuangan terhadap pertumbuhan wirausaha.

\section{ANALISIS DAN PEMBAHASAN Deskripsi Responden}

Tabel 1 menunjukkan deskripsi demografi responden yang di survei. Temuan menunjukkan bahwa sebagian besar (43,
94\%) responden berusia antara 40 sampai 49 tahun, kemudian disusul usia 30 sampai 39 tahun. Jumlah responden perempuan sedikit lebih banyak dibanding laki-laki yaitu sebesar $51,52 \%$.

Lapangan usaha responden yang paling banyak adalah industri $(39,40 \%)$ yang meliputi handycraft, herbal, konveksi, tahu, tempe, aneka makanan ringan (snack), dan abon. Sementara itu untuk lama usaha, yang paling banyak lama usahanya kurang dari 5 tahun yaitu sebanyak $25,76 \%$.

Tabel 1

Profil Responden

\begin{tabular}{lcc}
\hline \hline \multicolumn{1}{c}{ Variabel } & Frekuensi & Prosentase (\%) \\
\hline 1.Usia & 0 & 0 \\
Kurang dari 20 & 7 & 10,60 \\
tahun & 17 & 25,76 \\
20 - 29 tahun & 29 & 43,94 \\
30 - 39 tahun & 13 & 19,70 \\
40 - 49 tahun & & \\
Lebih dari 50 tahun & 32 & 48,48 \\
2.Jenis Kelamin & 34 & 51,52 \\
Laki-laki & & \\
Perempuan & 22 & 33,33 \\
3.Lapangan Usaha & 18 & 27,27 \\
Jasa & 26 & 39,40 \\
Perdagangan & & \\
Industri & 17 & 25,76 \\
4.Lama Usaha & 15 & 22,73 \\
Kurang dari 5 tahun & 14 & 21,21 \\
5 -9 tahun & 9 & 13,63 \\
10 - 14 tahun & 11 & 16,67 \\
15 - 19 tahun & & \\
Lebih dari 20 tahun & &
\end{tabular}

Uji Validitas Dan Reliabilitas Instrumen Penelitian

Uji validitas pada penelitian ini dilakukan dengan melihat nilai pearson correlation dari setiap item pertanyaanpernyataan yang diberikan kepada responden.
Uji validitas menunjukkan bahwa semua instrumen atau item pernyataan yang digunakan untuk mengukur keenam variabel mempunyai nilai pearson correlation di atas $r$ tabel $(0,243)$. Dengan demikian keseluruhan dari item pernyataan dinyatakan valid. 
Uji reliabilitas dengan menggunakan metode Cronbach's Alpha di mana pernyataan dinilai reliabel apabila Cronbach's Alpha $>0,60$. Hasil uji reliabilitas untuk semua variabel mempunyai koefisien Alpha $>0,60$. Dapat dinyatakan bahwa semua item variabel penelitian adalah reliabel dan dapat digunakan sebagai dasar pengumpulan data.

\section{Uji Asumsi Klasik}

Persyaratan yang harus dipenuhi dalam model regresi adalah data berdistribusi normal. Pengujian normalitas dengan uji One Sampel Kolmogorof-Smirnov, data dinyatakan berdistribusi normal jika signifikansi lebih besar dari 0,05 (Wiyono, 2011). Dengan menggunakan taraf signifikansi 0,05, nilai Asymp. Sig. (2-tailed) sebesar 0,768> dari 0,05. Dengan demikian data dinyatakan berdistribusi normal.

Persyaratan yang harus dipenuhi dalam model regresi adalah tidak ada hubungan linear antar variabel independen dalam model regresi (tidak ada multikolinearitas).

Tabel 2

Hasil Uji Normalitas

\begin{tabular}{llr}
\hline \hline & & Standardized Residual \\
\hline $\mathrm{N}$ & & 65 \\
Normal Parameters & $\mathrm{a}$ & 0,0000000 \\
& Mean & 0,96014322 \\
Deviation & Std & 0,665 \\
Kolmogorov-Smirnov Z & & 0,768 \\
Asymp. Sig. (2-tailed) & \\
\hline
\end{tabular}

Pengujian multikolinearitas dengan nilai varince inflation factor (VIF), apabila VIF $<5$ maka antar variabel independen tidak terjadi masalah multikolinearitas (Wiyono, 2011). Nilai variance inflation factor (VIF) variabel kebijakan dan prosedur pemerintah sebesar 1,686, variabel kondisi sosial ekonomi sebesar 1,810 variabel kewirausahaan dan ketrampilan sebesar 3,159 variabel bantuan keuangan sebesar 2,715 dan variabel bantuan non keuangan sebesar 3,676. Dari kelima variabel tersebut masing-masing hasilnya $<5$, sehingga dapat disimpulkan antar variabel independen tidak terjadi masalah multikolinearitas.

Tabel 3

Hasil Uji Multikolinearitas

\begin{tabular}{llcc}
\hline \multirow{2}{*}{ Model } & \multicolumn{2}{c}{ Collinearity Statictics } \\
\cline { 3 - 4 } & \multicolumn{2}{c}{ Tolerance } & VIF \\
\hline 1 & (Constant) & 0,593 & 1,686 \\
& Kebijakan \& Prosedur Pemerintah & 0,552 & 1,810 \\
Kondisi Sosial Ekonomi & 0,317 & 3,159 \\
Ketrampilan Kewirausahaan \& Bisnis & 0,368 & 2,715 \\
Bantuan Keuangan & 0,272 & 3,676 \\
\hline
\end{tabular}


Persyaratan yang harus dipenuhi dalam model regresi adalah tidak adanya varian dari residual untuk semua pengamatan dalam model regresi (tidak ada heteroskedastisitas). Pengujian heteroskedastisitas dengan uji park, yaitu meregresikan nilai residual (Lnei ${ }^{2}$ ) dengan masing-masing variabel independen. Apabila $-\mathrm{t}$ tabel $\leq \mathrm{t}$ hitung $\leq \mathrm{t}$ tabel maka tidak terjadi masalah multikolinearitas (Wiyono, 2011).

Hasil uji heteroskedastisitas menunjukkan nilai $\mathrm{t}$ hitung variabel kebijakan dan prosedur pemerintah sebesar -0,317, variabel kondisi sosial ekonomi sebesar -1,144, variabel ketrampilan kewirausahaan dan bisnis sebesar -0,272, variabel bantuan ekonomi sebesar 0,273, dan variabel bantuan non ekonomi sebesar $-0,744$, sedangkan $\mathrm{t}$ tabel dengan $\mathrm{df}=\mathrm{n}-2$ atau $66-2=64$, adalah sebesar 1,6690. Karena nilai $t$ hitung berada pada $-\mathrm{t}$ tabel $\leq \mathrm{t}$ hitung $\leq \mathrm{t}$ tabel, maka dapat disimpulkan bahwa tidak ditemukan masalah heteroskedastisitas pada model regresi.

Tabel 4

Hasil Uji Heterokedastisitas

\begin{tabular}{|c|c|c|c|c|c|}
\hline \multirow[t]{2}{*}{ Model } & \multicolumn{2}{|c|}{$\begin{array}{l}\text { Unstandardized } \\
\text { Coefficients }\end{array}$} & $\begin{array}{c}\text { Standardized } \\
\text { Coefficients }\end{array}$ & \multirow[t]{2}{*}{$\mathrm{T}$} & \multirow[t]{2}{*}{ Sig. } \\
\hline & B & Std. Error & Beta & & \\
\hline 1 (Constant) & 3,383 & 0,880 & & 3,843 & 0,000 \\
\hline Kebijakan \& Prosedur Pemerintah & $-0,011$ & 0,034 & $-0,050$ & $-0,317$ & 0,752 \\
\hline Kondisi Sosial Ekonomi & $-0,030$ & 0,026 & $-0,187$ & $-1,144$ & 0,257 \\
\hline Ketrampilan Kewirausahaan \& Bisnis & $-0,016$ & 0,058 & $-0,059$ & $-0,272$ & 0,787 \\
\hline Bantuan Keuangan & 0,011 & 0,042 & 0,055 & 0,273 & 0,786 \\
\hline Bantuan Non Keuangan & $-0,026$ & 0,035 & $-0,173$ & $-0,744$ & 0,460 \\
\hline
\end{tabular}

\section{Regresi Linier Berganda}

Analisis regresi linier berganda digunakan untuk mengetahui bagaimana naik turunnya serta arah hubungan variabel independen kebijakan dan prosedur pemerintah (KPP), kondisi sosial ekonomi, ketrampilan kewirausahaan dan bisnis, bantuan keuangan, dan bantuan non keuangan terhadap variabel dependen pertumbuhan wirausaha di Kabupaten Sleman. Dengan bantuan SPSS 17.00 diperoleh persamaan regresi linier berganda $\mathrm{PW}=$ $5,152-0,094 \mathrm{KPP}+0,142 \mathrm{KSE}+0,218 \mathrm{KKB}+$ $0,177 \mathrm{BK}+0,058 \mathrm{BNK}+$ e. Nilai Adjusted $R$ square sebesar 0,653 atau $65,3 \%$ artinya bahwa $65,3 \%$ variabel pertumbuhan wirausaha (PW) dapat dijelaskan oleh variabel kebijakan dan prosedur pemerintah, kondisi sosial ekonomi, ketrampilan kewirausahaan dan bisnis, bantuan keuangan, dan bantuan non keuangan, sedangkan 34\% dijelaskan oleh variabel lain.

\section{Uji Hipotesis}

Hasil uji $\mathrm{F}$ menunjukkan nilai probabilitas $P_{\text {value }}$ (sig) sebesar 0,000 kurang dari 0,05 . Hal ini menunjukkan bahwa H0 ditolak, artinya bahwa variabel bebas yang terdiri dari variabel kebijakan dan prosedur pemerintah, kondisi sosial ekonomi, ketrampilan kewirausahaan dan bisnis, bantuan keuangan, dan bantuan non keuangan secara simultan berpengaruh terhadap pertumbuhan wirausaha di Kabupaten Sleman. 
Tabel 5

Hasil Uji F

\begin{tabular}{lccccc}
\hline \hline & \multicolumn{5}{c}{ ANOVA $^{\mathrm{b}}$} \\
\hline Model & $\begin{array}{c}\text { Sum of } \\
\text { Squares }\end{array}$ & Df & Mean Square & F & Sig. \\
\hline 1 Regression & 298.385 & 5 & 39.277 & 25.122 & $.000^{\mathrm{a}}$ \\
Residual & 139.215 & 59 & 2.360 & & \\
Total & 435.600 & 64 & & & \\
\hline
\end{tabular}

Uji t (signifikansi parsial) menunjukkan sejauh mana pengaruh variabel bebas secara individual dalam menerangkan variasi variabel terikat (Wiyono, 2011). Dalam penelitian ini uji $t$ untuk mengetahui pengaruh variabel kebijakan dan prosedur pemerintah, kondisi sosial ekonomi, ketrampilan kewirausahaan dan bisnis, bantuan keuangan, dan bantuan non keuangan secara parsial terhadap pertumbuhan wirausaha di Kabupaten Sleman.

Tabel 6

Hasil Uji t dan Regresi

Coefficients ${ }^{a}$

\begin{tabular}{|c|c|c|c|c|c|}
\hline \multirow[t]{2}{*}{ Model } & \multicolumn{2}{|c|}{$\begin{array}{l}\text { Unstandardized } \\
\text { Coefficients }\end{array}$} & \multirow{2}{*}{$\begin{array}{c}\begin{array}{c}\text { Standardized } \\
\text { Coefficients }\end{array} \\
\text { Beta }\end{array}$} & \multirow[t]{2}{*}{$\mathbf{T}$} & \multirow[t]{2}{*}{ Sig. } \\
\hline & B & Std. Error & & & \\
\hline 1 (Constant) & 5,152 & 1,488 & & 3,463 & 0,001 \\
\hline Kebijakan \& Prosedur Pemerintah (KPP) & $-0,094$ & 0,057 & $-0,159$ & $-1,663$ & 0,102 \\
\hline Kondisi Sosial Ekonomi (KSE) & 0,142 & 0,044 & 0,323 & 3,262 & 0,002 \\
\hline Ketrampilan Kewirausahaan \& Bisnis (KKB) & 0,218 & 0,099 & 0,288 & 2,205 & 0,031 \\
\hline Bantuan Keuangan (BK) & 0,177 & 0,071 & 0,303 & 2,498 & 0,015 \\
\hline Bantuan Non Keuangan (BNK) & 0,058 & 0,059 & 0,139 & 0,982 & 0,330 \\
\hline
\end{tabular}

Hasil olah data dengan SPSS 17.00 menunjukkan nilai signifikansi variabel kebijakan dan prosedur pemerintah sebesar 0,102 , lebih besar dari nilai taraf signifikansi $(0,05)$. Dengan demikian secara parsial variabel kebijakan dan prosedur pemerintah tidak berpengaruh terhadap variabel pertumbuhan wirausaha. Temuan ini sangat mengejutkan, karena pemerintah telah menyusun berbagai kebijakan dan prosedur yang dimaksudkan untuk mendorong pertumbuhan wirausaha, karena dari berbagai penelitian terdahulu wirausaha dapat me- ningkatkan perekonomian, mengurangi pengangguran dan masalah sosial di masyarakat. dengan menyusun program yang berhubungan dengan infrastruktur seperti fasilitas jalan, jembatan, listrik, pemasaran dan jaringan, serta pendidikan dan pelatihan.

Untuk kondisi di kabupaten Sleman, infrastuktur jembatan dan jalan penghubung antar desa sudah ada dan bahkan sebagian besar sudah beraspal, dan semua wilayah sudah ada jaringan listrik, oleh karena itu pembangunan jalan, jembatan, 
dan jaringan listrik yang diharapkan dan memunculkan berbagai usaha seperti toko kelontong, rumah makan, bensin eceran dan SPBU, tambal ban, dan bengkel ternyata tidak berhasil.

Selain itu juga dilakukan dengan menyusun program non infrastruktur seperti peraturan perundangan dan lembaga yang diperlukan untuk mendukung pemberdayaan UMKM. Pusat Layanan Terpadu (PLUT) yang dimaksudkan untuk memberikan bantuan pemasaran dan jaringan serta berbagai pelatihan sesuai yang dibutuhkan wirausaha tenyata tidak berpengaruh terhadap pertumbuhan wirausaha. Adanya PLUT tidak mampu menarik seseorang untuk menjadi wirausaha, namun berfmanfaat bagi wirausaha yang sudah ada. Jika mereka mempunyai masalah dalam pengelolaan usahanya, mereka dapat meminta bantuan ke PLUT. Dalam proses pengumpulan data, sebagian besar responden menyatakan bahwa pemerintah telah berhasil melakukan pemangkasan perizinan, sehingga lebih mudah dan cepat.

Variabel bantuan non keuangan secara parsial tidak berpengaruh terhadap pertumbuhan wirausaha, yang ditunjukkan dengan nilai signifikansi t 0,330> dari taraf signifikansi 0,05. Berbagai program bantuan non keuangan dalam bentuk konseling baik melalui PLUT maupun dengan dinas terkait, inkubator, penelitian dan pengembangan, jaringan informasi, serta transportasi dan komunikasi secara parsial tidak berpengaruh terhadap pertumbuhan wirausaha. Dengan sampel penelitian semuanya adalah masyarakat yang mempunyai unit usaha, mereka tetap dapat menjalankan aktivitas usaha meskipun tanpa adanya bantuan non keuangan ini. Meskipun demikian agar wirausaha yang sudah ada ini meningkat kelasnya, maka bantuan non keuangan ini tetap diperlukan. Bantuan non keuangan ini tetap harus disediakan oleh pemerintah, sebagai buffer stock, jika sewaktu-waktu diperlukan oleh wirausaha.

Temuan ini berbeda dengan hasil penelitian Obaji dan Olugu (2014) yang menyatakan bahwa keberhasilan wirausaha di banyak negara banyak bergantung pada kebijakan pemerintah di negara tersebut. Hasil penelitian Setyawati et al. (2013 menyatakan bahwa pemerintah berperan dalam pertumbuhan usaha mebel dan anyaman rotan di Kabupaten Hulu Sungai Utara, Kalimantan Selatan. Dapat dijelaskan bahwa kondisi lingkungan di Kabupaten Sungai Utara yang belum semaju Kabupaten Sleman, sehingga peran pemerintah baik dalam bidang infrastruktur maupun non infrastruktur pengaruhnya akan lebih besar.

Hal lain yang dapat ditangkap pada proses pengumpulan data bahwa program kredit murah masih sulit untuk dapat dijangkau oleh wirausaha karena keterbatasan agunan. Modal Ventura meskipun demikian bagi wirausaha yang dapat mengakses kredit murah, mengakui adanya keringanan beban bunga yang harus mereka tanggung. Sementara untuk prosedur perizinan wirausaha menilai sudah mengalami perbaikan, baik dalam hal lamanya proses pengurusan maupun biaya yang lebih transparan.

Nilai signifikansi $t$ untuk variabel kondisi sosial ekonomi sebesar 0,002 lebih kecil dari nilai taraf signifikansi $(0,05)$. Dengan demikian, artinya secara parsial terdapat pengaruh antara variabel keadaan sosial ekonomi terhadap variabel pertumbuhan wirausaha. Variabel sosial ekonomi seperti sikap positif masyarakat terhadap wirausaha, adanya keluarga maupun 
contoh wirausaha sukses, berbagai bidang usaha yang dapat dilakukan oleh wirausaha, serta pertumbuhan ekonomi yang relatif tinggi mampu mendorong pertumbuhan wirausaha.

Upaya pemerintah untuk mewujudkan kondisi sosial ekonomi yang mendukung wirausaha ini dapat dilakukan dalam bentuk kampanye positif wirausaha, mengekspos dan memberikan penghargaan kepada wirausaha yang sukses, serta mempertahankan tingkat pertumbuhan ekonomi nasional. Lebih rinci lagi disebutkan oleh Lestari dan Wijaya (2012) bahwa untuk memunculkan wirausaha muda perempuan maka masyarakat harus dapat menghilangkan pandangan negatif terhadap wirausaha perempuan.

Nilai signifikansi $t$ untuk variabel ketrampilan kewirausahaan dan bisnis sebesar 0,031 lebih kecil dari nilai taraf signifikansi $(0,05)$. Dengan demikian, variabel kewirausahaan dan ketrampilan secara parsial berpengaruh signifikan dalam meningkatkan petumbuhan wirausaha di Kabupaten Sleman. Masyarakat yang mempunyai ketrampilan, jiwa, dan semangat wirausaha lebih yakin dalam menentukan wirausaha sebagai jalan hidupnya. Modal ketrampilan wirausaha dan bisnis membuat mereka yakin dengan pilihannya sebagai wirausaha, yakin mampu mengelola usahanya, dan yakin akan meraih kesuksesan dalam berwirausaha.

Keyakinan ini diperkuat dengan adanya sikap positif masyarakat terhadap wirausaha dan adanya dukungan finansial maupun non finansial dari pemerintah maupun lembaga lain. Temuan ini mendukung hasils penelitian Lestari dan Wijaya (2012) yang menyebutkan bahwa pendidikan kewirausahaan berpengaruh signifikan terhadap minat berwirausaha. Mahasiswa yang mendapat mata kuliah kewirausahaan lebih berminat untuk menjadi wirausaha dibanding mahasiswa yang tidak mendapatkan mata kuliah ini.

Pada umumnya wirausaha mengembangkan sendiri teori manajemen dan organisasi yang ada, disesuaikan dengan kondisi dan situasi yang dihadapi. Mengingat bahwa ketrampilan kewirausahaan dan bisnis secara parsial berpengaruh terhadap pertumbuhan wirausaha, maka ke depan perlu kajian tentang praktek manajemen yang diaplikasikan oleh wirausaha.

Nilai signifikansi $t$ untuk variabel bantuan keuangan sebesar 0,015 lebih kecil dari nilai taraf signifikansi $(0,05)$. Dengan demikian, variabel bantuan keuangan secara parsial berpengaruh dalam meningkatkan pertumbuhan wirausaha. Upaya pemerintah untuk meningkatkan jumlah wirausaha dan meningkatkan kelas wirausaha yang sudah ada dilakukan dengan modal ventura, kredit yang relatif murah, kesediaan lembaga keuangan termasuk perbankan dalam membiayai usaha kecil, dan adanya lembaga penjamin kredit.

\section{SIMPULAN DAN SARAN}

\section{Simpulan}

Variabel kebijakan dan prosedur pemerintah, kondisi sosial ekonomi, ketrampilan kewirausahaan dan bisnis, bantuan keuangan, dan bantuan non keuangan berpengaruh terhadap pertumbuhan wirausaha di kabupaten Sleman. Secara parsial, variabel kondisi sosial ekonomi, kewirausahaan dan ketrampilan, dan bantuan keuangan berpengaruh terhadap pertumbuhan wirausaha, sedangkan variabel kebijakan dan prosedur pemerintah dan bantuan non keuangan tidak berpengaruh terhadap pertumbuhan wirausaha. 
Berdasar analisis regresi linear berganda menunjukkan bahwa variabel kondisi sosial ekonomi, ketrampilan kewirausahaan dan bisnis, bantuan keuangan, dan bantuan non keuangan berpengaruh positif terhadap pertumbuhan wirausaha, sedang kebijakan dan prosedur pemerintah berpengaruh negatif terhadap pertumbuhan wirausaha. Implikasinya, apabila pemerintah bermaksud meningkatkan jumlah wirausaha, maka dari kelima variabel tersebut variabel ketrampilan dan kewirausahaan yang paling ditekankan.

Variabel kebijakan dan prosedur pemerintah, kondisi sosial ekonomi, ketrampilan kewirausahaan dan bisnis, bantuan keuangan, dan bantuan non keuangan mampu menjelaskan variasi pertumbuhan wirausaha di kabupaten Sleman.

\section{Saran}

Berdasar hasil penelitian ini, pertumbuhan wirausaha di kabupaten Sleman dapat ditingkatkan dengan menjaga kondisi sosial ekonomi yang kondusif, meningkatkan ketrampilan kewirausahaan dan bisnis, dan memberikan bantuan ekonomi kepada wirausaha. Variabel sosial ekonomi seperti sikap positif masyarakat terhadap wirausaha, adanya keluarga maupun contoh wirausaha sukses, berbagai bidang usaha yang dapat dilakukan oleh wirausaha, serta pertumbuhan ekonomi yang relatif tinggi mampu mendorong pertumbuhan wirausaha. Modal ketrampilan wirausaha dan bisnis membuat mereka yakin dengan pilihannya sebagai wirausaha, yakin mampu mengelola usahanya, dan yakin akan meraih kesuksesan dalam berwirausaha. Upaya pemerintah untuk meningkatkan jumlah wirausaha dan meningkatkan kelas wirausaha yang sudah ada dilakukan dengan modal ventura, kredit yang relatif murah, kesediaan lembaga keuangan termasuk perbankan dalam membiayai usaha kecil, dan adanya lembaga penjamin kredit.

Variabel kebijakan dan prosedur pemerintah yang diharapkan berpengaruh positif dan signifikan terhadap pertumbuhan wirausaha, ternyata justru sebaliknya, oleh karena itu perlu dilakukan kajian khusus tentang kebijakan dan prosedur pemerintah, sehingga kebijakan dan prosedur yang dibuat pemerintah benar-benar sesuai dengan kebutuhan wirausaha. Kebijakan kredit murah tanpa mengubah persyaratan dalam akses dana tidak akan berdampak signifikan pada pertumbuhan wirausaha, karena adanya keterbatasan agunan. Kebijakan pemberian peralatan menjadi tidak berdampak signifikan, karena tidak sesuai dengan kebutuhan wirausaha. Sementara kebijakan pemangkasan prosedur perizinan sudah dirasakan manfaatnya oleh wirausaha.

Variabel bantuan non keuangan secara parsial tidak berpengaruh terhadap pertumbuhan kewirausahaan, namun sebaik nya pemerintah dan lembaga pendidikan tetap menyelenggarakan bantuan non keuangan. Apabila dalam perjalannya adawirausaha yang membutuhkan bantuan misalnya dalam bentuk pemasaran online, informasi pasar, dan jaringan kewirausahaan bantuan tersebut siap diberikan.

\section{DAFTAR PUSTAKA}

Anonymous. 2008. Undang-undang Republik Indonesia Nomor 20 tahun 2008 Tentang Usaha Mikro Kecil dan Menengah (UMKM). Kementrain Koperasi dan UKM. Jakarta.

Ayuningtias, H. A. dan S. Ekawati. 2015. Faktor-faktor yang Mempengaruhi Minat Berwirausaha Pada Mahasiswa 
Fakultas Ekonomi Universitas Tarumanagara. Jurnal Ekonomi XX(01): 49-71.

Bygrave, W. D. 2004. The Portable MBA in Entrepreneurship. Third Edition. John Willey \& Sons Inc., New Jersey.

Chrissanti, M. A. dan F. Tjiptono. 2012. Faktor-faktor yang Memperngaruhi Intensi Berwirausaha di Kalangan Mahasiswa. Telaah Bisnis 13(1): 17-34.

Dian, R., R. I. Sundari, E. Riswanto, dan Paryanto. 2014. Peningkatan dan Pengembangan Daya Saing bagi UMKM Kripik Salak di Kabupaten Sleman. Telaah Bisnis 14(1): 30-40.

Fereidouni, H. G., T. A. Masron, D. Nikbin, and R. E. Amiri. 2010. Consequences of External Environment on Entrepreneurial Motivation in Iran. Asian Academy of Management Journal 15(2): 175-196

Gyawali, D. R. and D. S. Fogel (1994). Environments for Entrepreneurship Development: Key Dimention and research Implications. Intrepreneurship: Theory and Practice 18: 43-62. http:// www.researchgate. net/publication/ 263733348 diakses 5 September 2015.

Hadisoegondo, S. 2006. Upaya Penumbuhan Wirausaha Baru: Masalah dan Pendekatannya. Jurnal INFOKOP 29: 48-62.

Haryani, S. 2013. The Analysis of Entrepreneurship Intention of Santri in Pesantren (Islamic Boarding School) in Yogyakarta Special Region. Proceeding of The $4^{\text {th }}$ Global Islamic Marketing. Turkey: 106-112.

Janah, W. O. dan A. Winarno. 2015. Pengalaman Praktik Kerja Industri, Motivasi Berprestasi, dan Keyakinan Diri Pengaruhnya Terhadap Intensi Berwirausaha Siswa SMK. Jurnal Pendidikan Bisnis dan Manajemen 1(3): 214221.

Lestari, R. B. dan T. Wijaya. 2012. Pengaruh Pendidikan Wirausaha Terhadap Minat Berwirausaha Mahasiswa di STIE MDP, STMIK MDP, dan STIE MUSI. Jurnal Forum Bisnis dan Kewirausahaan 1(2): 112119.
Manurung, H. 2013. Peluang Kewirausahaan Sekolah Melalui Kreativitas dan Inovasi. Jurnal Bisnis dan Kewirausahaan 1 (1): 59-86.

Marini, C. K. dan S. Hamidah. 2014. Pengaruh Self-Efficacy, Lingkungan Keluarga, Dan Lingkungan Sekolah Terhadap Minat Berwirausaha Siswa SMK Jasa Boga. Jurnal Pendidikan Vokasi 4(2): 195 - 207.

Obaji, N. O., and U. O. Mercy. 2014. The Role of Government Policy in Entrepreneurship Development. Science Journal of Business and Management 2 (4): 109-115.

Setyawati, E. C. N., Nugraha, H. Susanta, dan A. Ilham. 2013. Karakteristik Kewirausahaan dan Lingkungan Bisnis Sebagai Faktor Penentu Pertumbuhan Usaha: Studi IKM Sentra Kerajinan Rotan Amuntai kabupaten Hulu Sungai Utara, Provinsi Kalimantan Selatan. Jurnal Administrasi Bisnis 2 (1): 41-50.

Rosmiati, D. T. S. Junias, dan Munawar. 2015. Sikap, Motivasi, dan Minat Berwirausaha Mahasiswa. Jurnal Manajemen Dan Kewirausahaan 17(1): 21-30.

Sijabat, S. 2012. Pengembangan Teknologi dan Pemasaran Produk KUKM Menuju Masyarakat Ekonomi ASEAN 2015. Jurnal INFOKOP 21: 94-130.

Supriyanto. 2009. Business Plan Sebagai Langkah Awal Memulai Usaha. Jurnal Ekonomi dan Pendidikan 6(1): 73-83.

Syarif, T. 2012. Dukungan Infrastruktur Dalam Proses Pemberdayaan Koperasi dan UMKM. Jurnal INFOKOP 21: 159186.

Wibowo, Y. S. dan R. Artati. 2012. Penguatan Infrastruktur Keuangan Bagi UMKM: Menyingsing MEA 2015. Jurnal INFOKOP 21: 36-52.

Winarno. 2010. Entrepreneurship Attitude. ENRICHMENT: Journal Of Management 1 (1): 66-76.

Wiyono, G. 2011. Merancang Penelitian Bisnis dengan alat analisis SPSS 17.0 \& SmartPLS 2.0. UPP STIM YKPN, Yogyakarta. 
Wulandari, A. 2009. Pengaruh Lingku- ngan Eksternal dan Lingkungan Internal Terhadap Orientasi Wirausaha Dalam Upaya Meningkatkan Kinerja Perusahaan. Jurnal Pengembangan Wirausaha 11(2): 142-152. 